\title{
STUDY OF LACTOSE INTOLERANCE IN CHILDREN BELOW 24 MONTHS
}

Shabd Singh Yadav' ${ }^{1}$ A.K.Rawat ${ }^{2}$, H.P. Singh ${ }^{3}$, Sunil Rao ${ }^{4}$.

1. Assistant professor, Department of Pediatrics, Shyam Shah Medical College, REWA

2. Professor, Department of Pediatrics, B.M.C, Sagar.

3. Professor, Department of Pediatrics, Shyam Shah Medical College, REWA.

4. Assistant professor, Department of Pediatrics, Shyam Shah Medical College, REWA.

\section{CORRESPONDING AUTHOR:}

Dr. Shabd Singh Yadav,

Assistant warden quarter,

Shrishthi girls hostel,

Doctor Colony, REWA (M.P).

E-mail:shabdsinghyadav@gmail.com

ABSTRACT: OBJECTIVE: To study the incidence of transient lactose intolerance in children below 24 months and to determine the need of discontinuation of breast feeding and necessity of lactose free formula. MATERIAL AND METHODS: Randomly selected 100 children below 24 months of age, who were admitted in department of pediatrics, S.S. Medical College and Associated G.M. Hospital Rewa, 70 of them were grouped as cases with diarrhea, abdominal distention, vomiting, perianal excoriation and 30 were age and sex matched control. After collection of stool, $\mathrm{pH}$, reducing substances in stool was determined and osazone test was performed to identify the types of reducing substances. RESULT: Out of 70 cases with diarrhoea, 22 (31.4\%) were found to have evidence of lactose intolerance. Besides loose motion, in lactose intolerance positive cases, most common presenting symptoms were abdominal distention, perianal excoriation and vomiting. Incidence of lactose intolerance was less in children who were on exclusive breast feeding till 6 months. In lactose intolerance positive as well as negative group duration of diarrhea after admission was same inspite of continuation of breast feeding. CONCLUSION: - Presence of abdominal distention, frothy character of stool, and perianal excoriation are suggestive of lactose intolerance. Lactose free formula and withdrawal of breast milk are not necessary in children with acute diarrhea and persistent diarrhea having transient lactose intolerance.

KEY WORDS: Lactose intolerance, Transient, Diarrhoea, Abdominal Distension.

INTRODUCTION: Diarrhoea is a very common problem in infancy and childhood, particularly in developing countries. It is second most common cause of mortality in under five children. The incidence of diarrhoea which persists following an acute attack, in spite of adequate treatment, is still high. Amongst the diverse etiological factors in these cases of persistent diarrhoea, carbohydrate intolerance has been shown to be a very important cause.

Lactose intolerance is a clinical syndrome of one or more of the following: abdominal pain, diarrhoea, nausea, flatulence and/or bloating after the ingestion of lactose or lactose containing food substances. The amount of lactose that will cause symptoms varies from individual to individual depending on the lactose consumed, degree of lactose deficiencies and the form of food substance in which the lactose is ingested. ${ }^{1}$

Lactose, a disaccharide that comprises the monosaccharide glucose and galactose, is the primary carbohydrate found exclusively in the mammalian milk. Absorption of lactose requires lactase activity in the small intestinal brush border. A beta galactosidase termed "lactase 
phlorizin hydrolase (lactase)" accounts for most of the lactase activity in the intestinal mucosa. Lactase is found in the small intestine and localize to the tips of villi. ${ }^{2}$

Lactose intolerance may be congenital, primary, secondary (Transient) and developmental. Congenital lactase deficiency is extremely rare. ${ }^{1}$ Although primary lactase deficiency is the most common cause of lactose intolerance but it manifests in late adolescence and adulthood. ${ }^{3}$

Secondary (transient) lactase deficiency is lactase deficiency that result from small bowel injury such as acute gastroenteritis, persistent diarrhea, cancer chemotherapy and can present at any age but is more common in infancy. ${ }^{1}$ Developmental lactase deficiency is defined as the relative lactase deficiency observed among preterm infants of less than 34 weeks gestation.

The purpose of present study is to find out the incidence of transient lactose intolerance in patient with diarrhoea, abdominal distension, perianal excoriation, vomiting and to determine the need of discontinuation of breast feeding and necessity of lactose free formula.

MATERIAL AND METHOD:- The study included 100 children below 24 months of age, 70 of them were cases with acute diarrhea or persistent diarrhoea, abdominal distention, perianal excoriation, vomiting; and 30 of them were control who did not have these features. The patients were selected from those admitted from June 2006 to Nov. 2007 in the Department of Pediatrics, S.S. Medical College and Associated G.M. Hospital Rewa (M.P). After selection, detailed history and physical examination was done. History included age, duration of illness, number and character of stool, vomiting, feeding history and past history of diarrhoea. In physical examination nude body weight, height, weight/ height ratio and head circumference was measured. Examination for abdominal distention, perianal excoriation was done. Stool was collected in plastic sheet to ensure complete collection of watery stool. Stool was then transferred to a clean container for further study. At first physical character of stool and then $\mathrm{pH}$ of stool by $\mathrm{pH}$ meter were noted. Reducing sugar was determined in watery portion of stool with Benedict's reagent.

$\begin{array}{lll}\text { Green Precipitate } & 0.1-0.5 \mathrm{gm} \% & (+1) \\ \text { Yellow Precipitate } & 0.5-1 \mathrm{gm} \% & (+2) \\ \text { Orange Precipitate } & 1-2 \mathrm{gm} \% & (+3) \\ \text { Red Precipitate } & >2 \mathrm{gm} \% & (+4)\end{array}$

Patients with diarrhoea, vomiting, abdominal distention or perianal excoriation, having $\mathrm{pH} \leq 5.5$ and reducing sugar $\geq 0.5-1 \mathrm{gm} \%(+2)$ were classified as sugar intolerance. These patients were taken for osazone test ${ }^{4}$ to differentiate the types of reducing sugar in stool sample on basis of shape of crystal seen under light microscope.

Osazone test is performed by adding 10 drops of glacial acetic acid to $5 \mathrm{ml}$ of sugar solution in a test tube, then add a knife point of phenyl hydrazine hydrochloride and double amount of sodium acetate crystals, mix them and filter the solution in another test tube. Boil the filtrate in water bath for 20 minutes, cool it slowly and then see the formation of crystals under light microscope as follows- 


\section{ORGINAL ARTICLE}

Osazone

Glucosazone

Fructosazone

Galactosazone

Lactosazone

Maltosazone
Min. time of formation

of crystals

5 minutes

2 minutes

7 minutes

10-12 minutes

10-15 minutes
Appearance of crystals

Broomstick like

Broomstick like

Rhombic like

Cotton wool like

Sunflower like

\section{RESULTS:-}

Out of 100 children, 70 were cases with diarrhoea, vomiting abdominal distention, perianal excoriation and 30 were age and sex matched control that did not have diarrhoea. Out of 70 cases, 49 were male and 21 female. Out of 30 control cases, 19 were male and 11 female. Among 70 cases, $22(31.4 \%)$ were found to have evidence of lactose intolerance. Among 30 controls no patient had evidence of intolerance to any sugar. About $86.36 \%$ cases of lactose intolerance were between 0 month -12 months of age. (Table - 1)

Besides loose motion, in lactose intolerance positive cases the presenting symptoms were abdominal distension (90.90\%), perianal excoriation (36.36\%), vomiting (32.0\%), fever $(18.0 \%)$, irritability $(0.4 \%)$ and in lactose intolerance negative cases symptoms were fever (69.0\%), vomiting (60.0\%), abdominal distension $(10.0 \%)$ and irritability $(8.3 \%)$ in decreasing order. In control most common presenting symptoms were fever and cough. (Table 2)

As shown in Table No. -3, character of stool was frothy in majority of lactose intolerance cases. Incidence of lactose intolerance was less (18.2\%) in children who were on exclusive breast feeding till 6 months and incidence of lactose intolerance was increases with feeding of top milk. (Table 4)

Duration of diarrhea was almost same in spite of continuation of breast feeding in both the groups. (Table 5)

DISCUSSION:- Amongst a total of 70 patients with diarrhoea, vomiting, abdominal distention and perianal excoriation, $22(31.4 \%)$ were found to have evidence of lactose intolerance, and 30 age and sex matched control cases without diarrhea admitted with fever, cough and vomiting had no evidence of lactose intolerance. In a study by Desai et al $^{5}$ in a series of 30 children with diarrhoea for $>7$ days, $50 \%$ had lactose intolerance.

Highest number of lactose intolerance cases (86.36\%) were in age group 0 month to 12 months in our study. Ansari et al (1979) ${ }^{6}$ have reported highest incidence in 6 months - 12 months age group. Incidence of diarrhoea and lactose intolerance during period of initiation of complimentary feeding is high probably because of higher incidence of gastrointestinal infections.

In our study abdominal distention (90.90\%), perianal excoriation (36.36\%) vomiting $(32.0 \%)$, fever $(18.0 \%)$, irritability $(0.4 \%)$, was the main presenting symptoms other than diarrhoea. Fermentation of unabsorbed disaccharide in large gut produces $\mathrm{CO}_{2}$ and fatty acid so that, these patients characteristically develop abdominal distention and frequent loose frothy stool of low $\mathrm{pH}$ resulting in perianal excoriation.

Stool was frothy in $77.2 \%$ and watery in $27.27 \%$ of lactose intolerance positive cases. In lactose intolerance negative cases, stool was frothy only in $10.41 \%$ and watery in $89.58 \%$. Premchander et al (1976) ${ }^{7}$ found similar pattern of stool output. 
In our study, all 70 cases were subjected to osazone test and classified as osazone test positive for lactose, glucose or maltose. Lactose was detected in 22 cases and no one was positive for glucose and maltose. This is similar to study by Ansari et al (1979) ${ }^{6}$ who found lactose as the offending sugar in all cases.

Duration of diarrhea after admission in lactose intolerance negative and positive groups was similar inspite of continued breast feeding in both the groups. Four cases with persistent diarrhoea ( $>14$ days duration), who had reducing sugar $\geq 2 \mathrm{gm} \%$ and stool $\mathrm{pH} \leq 5.5$ also recovered similarly, with continued breast feeding, however animal milk was stopped in all lactose intolerance positive cases, but lactose free formula was not prescribed to any patient and continuation of breast feeding had not caused prolongation of illness.

Presence of Abdominal distention, frothy character of stool, and perianal excoriation are suggestive of lactose intolerance.

Withdrawal of breast milk is not necessary in children with acute diarrhea and persistent diarrhea. Lactose free formulas are not necessary. Continuation of breast feeding had not caused prolongation of illness.

\section{REFERENCES:-}

1. American Academy of paediatrics: Lactose intolerance in infants, children and Adolescent; Paediatrics. 2006; 118(3):1280.

2. Semenza G. Anchoring and biosynthesis of stalked brush border membrane proteins: glycosidase and peptidase of enterocytes and renal tubuli. Ann. Rev. of Cell Biol. 1986; 2:255-313.

3. Kretchmer N. Lactose and Lactase: a historical perspective. Gastroenterology. 1971; 61:805-813.

4. Dev A.C. Viva and practical Biochemistry. 2004; 2:7-8.

5. Desai AB, Gandhi RA, and Vani GB: Lactose Intolerance: Indian pediatrics 1969; 6:457-462.

6. Ansari Z, Malik AS, Dutta AK, Ahmed SH, Saiahuddin: Prevalence of Sugar intolerance in diarrhoea of infancy and childhood. Indian Pediatrics Oct. 1979; 16(10):879-85.

7. Premchander KV, Sundaravalli N, Panchatcharam M.: Pattern of sugar intolerance in children following chronic or recurrent diarrhea: A preliminary report. Indian Pediatrics Mar. 1976; 13(3):177-86. 
Table - 1: Age wise distribution of Lactose Intolerance Positive Cases, Negative Cases and Control

\begin{tabular}{|c|c|c|c|c|c|c|}
\hline \multirow[t]{3}{*}{ Age in month } & \multicolumn{4}{|c|}{ Lactose Intolerance $(\mathrm{N}=70)$} & \multirow{2}{*}{\multicolumn{2}{|c|}{ Control $(\mathrm{N}=30)$}} \\
\hline & \multicolumn{2}{|c|}{$\begin{array}{l}\text { Negative Cases } \\
\qquad(\mathrm{N}=48)\end{array}$} & \multicolumn{2}{|c|}{$\begin{array}{l}\text { Positive cases } \\
\qquad(\mathrm{N}=22)\end{array}$} & & \\
\hline & No. & $\%$ & No. & $\%$ & No. & $\%$ \\
\hline $0-1$ & & $(4.0 \%)$ & 3 & $(13.63 \%)$ & 11 & $(36.6 \%)$ \\
\hline $1-6$ & & $(27.0 \%)$ & 9 & $(40.90 \%)$ & 7 & $(23.3 \%)$ \\
\hline $6-12$ & & $(41.6 \%)$ & 7 & $(31.81)$ & 7 & $(23.3 \%)$ \\
\hline $12-24$ & & $(27.0 \%)$ & 3 & $(13.63)$ & 5 & $(16.6)$ \\
\hline Total & 48 & (100.0\%) & 22 & $(100.0)$ & 30 & (100.0) \\
\hline
\end{tabular}

Table - 2: Presenting symptoms of lactose intolerance positive cases, negative cases and control

\begin{tabular}{|l|c|c|c|}
\hline Presenting Symptoms & $\begin{array}{c}\text { Positive Cases } \\
\text { (N-=22) }\end{array}$ & $\begin{array}{c}\text { Negative Cases } \\
\text { (N=48) }\end{array}$ & $\begin{array}{c}\text { Control } \\
\text { (N=30) }\end{array}$ \\
\hline Abdominal distension & 2 & 5 & - \\
\hline $\begin{array}{l}\text { Abdominal distention }+ \\
\text { vomiting }\end{array}$ & 7 & - & - \\
\hline $\begin{array}{l}\text { Abdominal distention }+ \\
\text { irritability }\end{array}$ & 1 & - & - \\
\hline $\begin{array}{l}\text { Abdominal distention }+ \\
\text { Perianal excoriation }+ \\
\text { irritability }\end{array}$ & 8 & - & - \\
\hline $\begin{array}{l}\text { Abdominal distention }+ \\
\text { fever }\end{array}$ & 2 & - & 18 \\
\hline Cough + fever & - & 10 & 05 \\
\hline Fever + vomiting & 2 & 19 & 05 \\
\hline Fever + irritability & - & 4 & 02 \\
\hline vomiting & - & 10 & - \\
\hline
\end{tabular}


Table - 3: Showing character of stool in lactose intolerance positive and negative

\begin{tabular}{|c|c|c|c|c|}
\hline \multirow[t]{2}{*}{ Type of Stool } & \multicolumn{2}{|c|}{$\begin{array}{l}\text { Positive cases } \\
\qquad(n=22)\end{array}$} & \multicolumn{2}{|c|}{$\begin{array}{l}\text { Negative cases } \\
\quad(\mathrm{N}=48)\end{array}$} \\
\hline & No. & $\%$ & No. & $\%$ \\
\hline Frothy & 17 & $(77.2)$ & 05 & $(10.41)$ \\
\hline Watery & 05 & $(27.27)$ & 43 & $(89.59)$ \\
\hline Associated with blood and mucus & 00 & - & 00 & - \\
\hline Total & 22 & $(100.0)$ & 48 & $(100.0)$ \\
\hline
\end{tabular}

$\chi 2=31.28 \quad \mathrm{p}<0.0001$ Highly Significant

Table - 4: Showing feeding pattern of cases and control

\begin{tabular}{|c|c|c|c|c|c|c|}
\hline \multirow[t]{3}{*}{ Feeding pattern } & \multicolumn{4}{|c|}{ Cases $(n=70)$} & \multirow{2}{*}{\multicolumn{2}{|c|}{ Control $(\mathrm{N}=30)$}} \\
\hline & \multicolumn{2}{|c|}{$\begin{array}{c}\text { Positive Cases } \\
(\mathrm{N}-=22)\end{array}$} & \multicolumn{2}{|c|}{$\begin{array}{l}\text { Negative Cases } \\
(\mathrm{N}=48)\end{array}$} & & \\
\hline & No. & $\%$ & No. & $\%$ & No. & $\%$ \\
\hline $\begin{array}{l}\text { Exclusive breast } \\
\text { Feeding upto } 6 \text { months }\end{array}$ & 04 & (18.2) & 23 & $(48.0)$ & 18 & $(60.0)$ \\
\hline $\begin{array}{l}\text { Breast feeding }+ \text { top } \\
\text { milk }\end{array}$ & 07 & (31.8) & 20 & $(42.0)$ & 06 & $(20.0)$ \\
\hline Top Milk & 11 & $(50.0)$ & 5 & $(10.0)$ & 06 & $(20.0)$ \\
\hline
\end{tabular}

$\chi 2=14.179 \quad \mathrm{p}<0.0008$ Highly Significant

Table - 5: Effect of breast feeding on lactose intolerance and duration of diarrhoea

\begin{tabular}{|c|c|c|c|c|}
\hline \multirow{3}{*}{$\begin{array}{l}\text { Duration in } \\
\text { days }\end{array}$} & \multicolumn{4}{|c|}{ Lactose Intolerance } \\
\hline & \multicolumn{2}{|c|}{ Negative cases $(n=48)$} & \multicolumn{2}{|c|}{$\begin{array}{c}\text { Positive cases } \\
(n=22)\end{array}$} \\
\hline & No & $\%$ & No & $\%$ \\
\hline $0-5$ & 42 & 87.5 & 19 & 86.3 \\
\hline $6-10$ & 6 & 12.5 & 3 & 13.6 \\
\hline $11-15$ & - & - & - & - \\
\hline$>15$ & - & - & - & - \\
\hline Total & 48 & 100.0 & 22 & 100.0 \\
\hline
\end{tabular}

$\chi 2=0.01739 \quad \mathrm{p}=0.89>0.05$ Not significant 